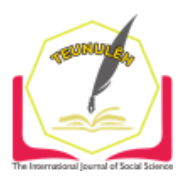

Jurnal Ilmiah Teunuleh

The International Journal of Social Sciences

Vol. 2, Issue. 2, June 2021

E-ISSN: $2746-4393$

\title{
PORTFOLIO ASSESSMENT IN PRIMARY SCHOOLS
}

\author{
M. Khairu Rizal ${ }^{1}$ \\ Universitas Negeri Lampung \\ mkhairu4001@gmail.com \\ Rochmiyati $^{2}$ \\ rochmiyatiazwardi@yahoo.co.id \\ Alben Ambarita ${ }^{3}$ \\ alben_ambarita57@yahoo.com \\ Een Yayah Haenilah 4 \\ eenhaenilah@gmail.com
}

\begin{abstract}
The purpose of this study is to describe the portfolio assessment conducted by the teacher on students and to describe the results of the use of the portfolio assessment. This study uses a qualitative method. This research is to obtain descriptive data regarding the implementation of the portfolio assessment conducted by the teacher on students, and a description of the results obtained by the teacher and students in carrying out the portfolio assessment process. From the results of this study, it can be seen thatteachers should be prepared to make written and standardized assessment criteria when they have decided to use portfolio assessment so that the assessment is carried out in accordance with existing achievement indicators. However, from the data seen, teachers often assess student assignments outside of learning hours so that the involvement of students in the assessment process is still not illustrated.
\end{abstract}

Keywords: Portfolio Assessment, Elementary School, Education Quality

\section{A. Introduction}

The implementation of the 2013 Curriculum is the government's effort to improve the quality of education and realize the goals of national education in Indonesia. The Indonesian government has formulated it in accordance with the Regulation of the Minister of Education and Culture of the Republic of Indonesia Number 81A of 2013 concerning the implementation of the curriculum in elementary schools which is carried 
out in stages in the 2013/2014 school year. Learning in elementary schools in the 2013 curriculum uses integrated thematic learning with the aim that students are active in learning activities and are able to connect one knowledge to another so that students see knowledge as a unified whole.

Learning and assessment are inseparable things, because assessment is the main component of a teacher's job in utilizing the results of the assessment of teaching and learning progress as information material in improving the teaching and learning process in the future. Assessment is a series of activities to obtain, analyze, and interpret data about the process and learning outcomes of students which are carried out systematically and continuously, so that they become objective information in decision making. (Purwanti, et.al., 2008, p. 6).

Assessment or assessment is one of the important aspects in learning, because it serves to assess the extent to which students can achieve the objectives of learning. Assessment has a broad scope ranging from mandatory or optional activities/tasks for students in learning and the suitability of certain forms of assessment is influenced by considerations of disciplines and types of learning that are recorded (Zacharis, 2010, p. 61). One form of assessment used in the 2013 Curriculum is authentic assessment.

Authentic assessment has various advantages when implemented in learning. Muller (2016) states that authentic assessment has the following benefits. First, it allows direct data collection of students' abilities. Second, train students not only to memorize material, but to understand the context of its use and construct their abilities in everyday life. Third, can integrate learning, teaching, and assessment activities as a whole and interrelated. Fourth, provide opportunities for students to show their abilities as best they can. In addition to these four benefits, the results of authentic assessments can be used by teachers as well as possible for the development needs of students.

Authentic assessment in the 2013 curriculum, which focuses on knowledge through input assessment to be ability-based through process assessment, portfolio and output assessment as a whole and comprehensive (Mulyasa, 2013: 135). Authentic assessment in learning assesses student achievement through direct measurement of students' actual performance on the competencies set by the teacher (Zulantay \& Olfos, 2007, p. 157). One form of authentic assessment in learning that is supportive and appropriate for assessing and learning process of students is portfolio assessment.

According to Permendikbud No. 81 A of 2013 that portfolio assessment is an ongoing assessment based on a collection of information that shows the development of 
students' abilities in a certain period. Portfolio assessment according to Gadbury-Amyot et al (2003, p. 911), Aziz \& Yusoff (2015, p. 46) is a set of tasks or student work that is specifically selected to describe the development and achievement of student skills in one period. Portfolio assessment emphasizes the assessment of the work/tasks of selected students, to see the progress of students through the assessment results they have achieved (Mahanal, 2006, p. 335). Teachers carry out assessments assisted by data collection tools or assessment instruments to record student competency achievements.

Portfolio assessment provides opportunities for students to be more actively involved and students easily control the development of the abilities they have acquired. Students are able to plan improvements, find their own strengths and weaknesses, and the ability to use these strengths in overcoming the weaknesses that exist in students. This is in line with the research of Yurdabakan and Erdogan (2013, p. 532), which explains that portfolio assessment has a significant effect on writing, reading, and listening skills. Portfolio assessment can increase students' responsibility, motivation, self-evaluation, and improve student work from time to time. Meanwhile, according to the results of research by Awang et.al $(2013$, p. 6) that the portfolio is more attractive to students. While the average learning achievement is better with a portfolio, students with low achievement do not use a portfolio. The average achievement of students performs portfolio assignments better than usual assignments, and finds portfolio assignments easier than traditional learning.

A preliminary study of educators' opinions on portfolio assessment instruments at SD Negeri 1 Dente Makmur, SD Negeri 1 Way Dente, SD Negeri 1 Teladas and SD Private Sinar Palembang involving 8 respondents of fifth grade teachers in the Hang Tuah cluster, the results show that $50 \%$ of educators have used the assessment portfolio, but educators lack mastery and lack of understanding of how to use portfolio assessment. Therefore, elementary school educators need a portfolio assessment instrument that is clear, simple, and easy to understand.

Teachers can use portfolio assessment instruments to assess and see the development of abilities and academic achievements of students during that period. For teachers, this file containing the progress of students will provide input for the assessment process in improving the ways, methods, and management of learning in the classroom. Through portfolio file analysis, teachers can find out the potential, character, strengths, and weaknesses of the students themselves. This file can be used as a basis for correcting and correcting strengths and weaknesses in the learning process as well as 
mastery of a basic competency or subject. The process of feedback is very possible because in the portfolio assessment system the data recorded in the file is not only collected and then completed,

\section{B. Research Method}

This study uses a qualitative approach. Qualitative approach is used to describe, describe, explore and describe related to this research. This study uses a literature study method which is a review of the literature from journals. Based on the purpose of this study is to describe the portfolio assessment conducted by the teacher to students and describe the results of the use of the portfolio assessment.

This research is to obtain descriptive data regarding the implementation of the portfolio assessment conducted by the teacher on students, and a description of the results obtained by the teacher and students in carrying out the portfolio assessment process. The data sources of this research are; portfolio assessment activities carried out by class teachers and students in class $V$ in elementary schools.

Data collection techniques in this study used the following instruments or observation sheets.

Table 1. Observation sheet indicators

\begin{tabular}{|c|c|c|}
\hline No & Component & Indicator \\
\hline \multirow[t]{2}{*}{1} & \multirow[t]{2}{*}{ Portfolio Content } & $\begin{array}{l}\text { The teacher gives assignments according to the } \\
\text { existing basic competencies }\end{array}$ \\
\hline & & $\begin{array}{l}\text { Teachers provide opportunities for } \\
\text { students to make improvements to assignments }\end{array}$ \\
\hline \multirow[t]{3}{*}{2} & \multirow{3}{*}{$\begin{array}{l}\text { Content assessment criteria } \\
\text { portfolio }\end{array}$} & The teacher prepares the assessment format \\
\hline & & $\begin{array}{l}\text { Teachers involve students in the assessment } \\
\text { process }\end{array}$ \\
\hline & & $\begin{array}{l}\text { The teacher gives notes to the student's } \\
\text { portfolio }\end{array}$ \\
\hline 3 & $\begin{array}{l}\text { Presentation form } \\
\text { portfolio }\end{array}$ & $\begin{array}{l}\text { Completed portfolio, } \\
\text { namely: cover, student identity, } \\
\text { document table of contents, document } \\
\text { boundaries, } \\
\text { teacher and parent notes. }\end{array}$ \\
\hline
\end{tabular}

Furthermore, interview guidelines need to be prepared so that the interview process does not deviate from the research focus. This interview aims to obtain data through direct question and answer. With the following grid; 
Portfolio Assessment in Primary Schools

Table 2. Interview guide indicators

\begin{tabular}{|c|l|}
\hline Aspect & \multicolumn{1}{|c|}{ Indicator } \\
\hline \multirow{3}{*}{ Teacher } & Fill portfolio \\
\cline { 2 - 3 } & Portfolio content assessment criteria \\
\cline { 2 - 3 } & $\begin{array}{l}\text { Determine the format and scale of assessment in assessing } \\
\text { student portfolios }\end{array}$ \\
\cline { 2 - 3 } & Notes or descriptive information provided \\
\cline { 2 - 3 } & Portfolio assessment presentation form \\
\cline { 2 - 2 } & Teacher constraints in carrying out portfolio assessment \\
\hline
\end{tabular}

In analyzing the data obtained by the researcher, the researcher used the model of Miles and Hubermen (1990). The model is to carry out the stages that begin with collecting data, reducing, displaying data, and verifying or drawing final conclusions. This activity was developed by the researcher with reference to the opinion of Mukhtar (2013, p. 135) with the Miles and Huberman (1990) model. Thus, what the researcher did in this analysis activity was to carry out the stages of analyzing the data as follows:

1. Collecting data, namely all the results of data from observations and interviews conducted, which are called raw data;

2. Reducing data, after collecting the data, the researcher selects the data, simplifies, focuses, and categorizes the data that has been obtained in the field. After that, the researcher abstracted or made a summary of the data;

3. Displaying data, compiling information and checking the validity of the data in an effort to draw conclusions;

4. Verify data, draw conclusions, analyze, and decide how to carry out portfolio assessment;

5. Make a report;

\section{Results and Discussion}

Based on interviews conducted, information was obtained that some teachers before deciding what content students would make to fill their portfolios, teachers made preparations in assessing, including; 1 ) adjust the task to the current curriculum, namely $\mathrm{K} 13,2$ ) determine what items must be obtained in the portfolio assignment, 3) determine the length of the portfolio made, and 4) have a scoring guideline.

Furthermore, the results of the contents of student portfolios can include; daily tests, book reading reports, self-assessment sheets, inter-theme assessment sheets, and for class $\mathrm{V}$ also included homework books, exercise books. The contents of the portfolio 
are also sourced from the LKPD which was developed by the teacher with the 2013 curriculum, so that the competencies in the task are deepest in the 2013 curriculum.

In planning a portfolio assessment, the teacher arranges the development of an assessment system and learning tools, determines the type of bill and the form of the instrument to be used. The development of the assessment system is integrated into the syllabus. The learning tools made include: Annual Programs, Semester Programs, and Lesson Plans. Details of the development of the assessment system that are integrated into the syllabus, which contains educational units, themes/subthemes, classes, content competencies, basic competencies, indicators, learning objectives, subject matter, time allocation, learning resources, and assessments. Assessment, including types of invoices, assessment criteria, and assessment sheets. In making this syllabus and assessment system, it is guided by the current curriculum, namely the 2013 curriculum.

However, even though they do not develop assessment criteria, teachers can provide scores for assignments that have been done by students. This is illustrated in the image below. From the results of interviews obtained data that the teacher assesses student assignments based on the concept that the teacher has on the material. After conducting an assessment of the students' assignments which resulted in a score ranging from 10-100. The teacher writes down the students' scores in the daily assessment book, as well as the teacher's daily agenda. The data obtained from the interviews with the VA class teachers are that the class teachers did not develop an assessment format in the lesson plans or in the student assignment sheets. This happened because in terms of insufficient time to make an assessment format. So that the notes that the teacher should write in the assessment format to comment on the results of student assignments, the teacher writes directly on the assignment sheet, in the form of motivational words such as "Improve Again". As an assessment instrument, the portfolio that the teacher takes is focused on documents about student work, namely "evidence" about what students can do, not what cannot be done.

Based on the results of the interview, it can be seen that the indicators in portfolio assessment are as follows,

1. The value of formative and summative test results. The formative test is held after completing one basic competency, while the summative test is held at the end of the semester. The value of the test results is recorded in the teacher's list of values and also recorded in the recapitulation of the individual scores of each student by including the basic competencies/materials, when the test was carried out, how 
many scores were obtained by students, the average value of the formative and summative tests for documented in the portfolio of each student.

2. Structured tasks (Homework). Structured tasks are tasks that are carried out by students to explore or expand their mastery of the subject matter. The tasks given can be in the form of practice questions contained in the Student Worksheet (LKPD). Assignment files after being graded are returned to students to be attached to each student's portfolio.

When preparing a portfolio, the teacher does not depict asking students to do a self-assessment. The Portfolio section developed by the teacher only has the front page and student identities. The researcher did not see the contents of the document, document boundaries, teacher and parent notes.

Using portfolios for assessment requires a lot of time from the teacher to do the scoring; especially if the class is big. The use of a portfolio depends on the ability of students to convey a written description. As long as students are not fluent in written Indonesian, the use of portfolios will be an additional burden that burdens most students. However, if portfolio assessment is used properly and correctly, it can strengthen the relationship between the learning process and the assessment.

\section{Conclusion}

The contents of the student portfolio developed by the teacher include daily tests, book reading reports, self-assessment sheets, inter-theme assessment sheets developed with the 2013 curriculum. Teachers should be ready to make written and standardized assessment criteria when they have decided to use portfolio assessment. so that the assessment carried out is in accordance with the existing achievement indicators. However, from the data seen, teachers often assess student assignments outside of learning hours so that the involvement of students in the assessment process is still not illustrated. Teachers should involve students in the assessment process so that students know their strengths and weaknesses.

\section{Bibliography}

Awang, M. M., Ahmad, A. R., Bakar, N. A., Ghani, S. A., Yunus, A. N., Ibrahim, M. A., . . . Rahman, M. J. (2013). Students' Attitudes and Their Academic Performance in 
Nationhood Education. International Education Studies, 6(11), 21-28. doi:10.5539/ies.v6n11p21

Aziz, M. N., \& Yusoff, N. M. (2015). Using Portfolio to Assess Rural Young Learners' Writing Skills in English Language Classroom. The Malaysian Online Journal of Educational Science, 3(4), 46-54.

Charoenchai, C., Phuseeorn, S., \& Phengsawat, W. (2015). Teachers' Development Model to Authentic Assessment by Empowerment Evaluation Approach. Academic Journals, 10(17), 2524-2531.

Gadbury-Amyot, C. C., Kim, J., Palm, R. L., Mills, G. E., Noble, E., \& Overman, P. R. (2003). Validity and Reliability of Portfolio Assessment of Competency in a Baccalaureate Dental Hygiene Program. Journal of Dental Education, 67(9), 991-1002. doi:10.1002/j.0022-0337.2003.67.9.tb03697.x

Mahanal, S. 2006. Suatu Contoh Implementasi Portofolio Sebagai Asesmen Autentik pada Mata Pelajaran Sains di Sekolah Dasar. Makalah disajikan pada SEMINAR NASIONAL MIPA 2006 FMIPA UNY, Yogyakarta pada tanggal 1 Agustus 2006. Dalam database, (http://eprints.uny.ac.id, Diakses 19 Juni 2021.

Muller, J. 2016. Authentic Assessment Toolbox: Portfolios. (jfmueller.faculty.noctrl. edu/toolbox/portfolios.htm.

Mulyasa. 2014. Pengembangan dan Implementasi Kurikulum 2013. Bandung: PT Remaja Rosdakarya.

Permendikbud. 2013. Implementasi Kurikulum 2013 No 81 A. Kemendikbud: Jakarta.

Purwanti, et, al. 2008. Assesmen Pembelajaran SD. Depdiknas: Jakarta.

Yurdabakan, Irfan. Erdogan Tolgan. (2013). The Effect of Portofolio Assement on Reading, listening, and Writing Skills of Secondary Prep Class Student. Online. International Journal of Education Research, 2(9), 527-538.

Zacharis, N.T. (2010). Innovative Assessment for Learning Enhancement: Issues and Practices. Contemporary Issues in Education Research, 3(1), 61-70.

Zulantay, H. \& Olfos, R. (2007). Reliability and Validity of Authentic Assessment in a Web Based Course. a Web Based Course. Educational Technology \& Society, 10(4), 156173. 